\title{
Performance, Ingestive Behavior and Gastrointestinal Helminths Control of Suckling Lambs Supplemented in Creep-Fed and Not Supplemented in Tropical Pastures
}

Gleice Kelli Ayardes de Melo, Camila Celeste Brandão Ferreira Ítavo, Luís Carlos Vinhas Ítavo (Corresponding author), Fernando de Almeida Borges, Alexandre Menezes Dias, Maria da Graça Morais, Jonilson Araújo da Silva, Pâmila Carolini Gonçalves da Silva, Kedma Leonora Silva Monteiro Ferelli

Faculty of Veterinary Medicine and Animal Science, Federal University of Mato Grosso do Sul, Avenida Senador Filinto Müller, 2,443, Campo Grande, CEP 79074-460, Mato

Grosso do Sul, Brazil. E-mail: luis.itavo@ufms.br

Fernando Alvarenga Reis

Embrapa Beef Cattle, Campo Grande, Brazil, Av. Rádio Maia, 830 - Vila Popular, C.P. 79106-550, Campo Grande, Mato Grosso do Sul, Brasil.

Received: August 15, 2019

Accepted: Sep. 8, 2019

Published: Sep. 9, 2019

doi:10.5296/jas.v7i4.15415

URL: https://doi.org/10.5296/jas.v7i4.15415

\begin{abstract}
The objective of this study was to evaluate the performance, ingestive behavior and gastrointestinal helminths control of suckling lambs raised on pastures of Brachiaria ssp. supplemented in creep-fed and not supplemented. Thirty-one lambs being 15 lambs in the control treatment (without supplementation) and 16 lambs in the creep feeding treatment (with protein-energetic supplementation) were evaluated. Performance of lambs supplemented was superior to lambs no-supplemented. Lambs without supplemented had weaning age of 81 days and an average gain of 194 grams. Lambs supplemented showed weaning age of 58 days and average daily gain of 268 grams. eggs per gram of stool (EPG) count in the control treatment was 4553 , while in the creep feeding treatment the mean was 763 . The morbidity rate caused by gastrointestinal helminths in the control treatment was $6.6 \%$ and there was no morbidity due to helminths in the treatment creep feeding. The morbidity rate due to hepatogenic intoxication was $46.6 \%$ in control and $12.5 \%$ in the lambs supplemented. The ingestion of protein-energy supplementation in creep feeding promoted an increase in productive performance of lambs, as well as increased resistance and tolerance to gastrointestinal infections and decreased cases of
\end{abstract}


hepatogenic intoxication by ingestion of Brachiaria spp.

Keywords: ingestive behavior; weight gain; Brachiaria poisoning; gastrointestinal helminths; small ruminants

\section{Introduction}

Brachiaria grasses, native to Africa, was widely reported in Brazil, make viable livestock farming in tropical regions because they adapt to the edaphoclimatic conditions and low soil fertility requirements (Euclides et al. 2009; Oliveira et al. 2019), but also the productive performance of lambs in pastures of Brachiaria spp. being influenced by the ability of these animals to harvest nutrients and by the availability of fodder (Emerenciano Neto et al. 2019), depends on factors such as stress caused by parasitism-related adversities (Melo et al. 2017) and hepatogenic intoxication by the consumption of Brachiaria spp. (Pupin et al. 2016; Melo et al. 2018).

The production of lambs in pastures of Brachiaria spp. is still poorly studied and has difficulties in its development due to lack of information on nutritional, sanitary and reproductive management. From the nutritional point of view, viable alternatives to the pasture production system are sought, especially for lambs, which are the ovine category of better-feed conversion and higher growth capacity (Garcia et al. 2003).

The objective of this study was to evaluate the performance of suckling lambs raised in Brachiaria ssp pastures receiving protein-energy supplementation in creep feeding system and lambs not supplemented.

\section{Material and Methods}

\subsection{Ethics Committee}

The experiment was approved by the ethics committee on the use of animals (CEUA-UFMS) under protocol no. 481/2012.

\subsection{Location and Experimental Period}

The project was carried out at the Experimental Farm (20²6'34.31"S 54 $50^{\prime} 27.86^{\prime \prime O}, 530.7 \mathrm{~m}$ altitude) of the Faculty of Veterinary Medicine and Animal Science (FAMEZ) of the Federal University of Mato Grosso do Sul (UFMS) - Brazil. The experiment started on May 5, 2013 with the first calving and ended on October 3, 2013 with weaning lambs, characterizing the breeding phase as an experimental period.

\subsection{Animals}

The lambs were the offspring of no defined race wes crossed with an Ile de France breeder and offspring of Santa Inês and Dorper crossbred sheep with a White Dorper breeder.

\subsection{Experimental Area}

\subsubsection{Pastures}

The lambs and their respective mothers were kept in pasture composed by Brachiaria 
brizantha and B. decumbens in an area of 4.77 ha divided in six pickets (three per treatment).

\subsubsection{Creep-Fed}

The internal area of creep feeding corresponded to $2.6 \mathrm{~m}^{2}(2.00 \mathrm{~m} \times 1.30 \mathrm{~m})$. The troughs remained inside wooden enclosures, provided with opening systems with dimensions of 30 $\mathrm{cm}$ in height and $20 \mathrm{~cm}$ in width.

\subsection{Nutritional Management}

In the treatment of creep feeding the protein-energy supplement (Table 1) was provided in the morning and the lambs had free access to the creep fed all day. Daily weights of the quantities supplied and leftovers were calculated for the calculation of the average daily consumption of the concentrate. All lactating mothers received $350 \mathrm{~g} /$ day of protein-energy supplementation (Table 1) based on corn, milled grain and soybean meal to meet approximately $30 \%$ of the total requirement (maintenance + lactation) in the stage of lactation of sheep with $50 \mathrm{~kg}$ of body weight (CP) and a dry matter intake (DMI) of $1.26 \mathrm{~kg}$ according to NRC (2007). Water and mineral supplement were available ad libitum to animals.

\subsection{Experimental Treatments}

The treatments consisted of two different forms of supplementation. (1) Control treatment: Brachiaria spp. + mineral supplementation + suckling; (2) Creep feeding treatment: Brachiaria spp + mineral supplementation + suckling + concentrated protein-energy supplementation in creep fed.

After birth the lambs were distributed in control and creep feeding treatments. In the control treatment were used nine male lambs and six females (15 lambs), from simple and twin calving. In the treatment creep feeding were used nine male lambs and seven females (16 lambs), from single and twin calving.

\subsection{Ingestive Behavior Analysis}

The evaluation of the ingestive behavior of lambs was performed every 14 days, from sunrise to sunset, corresponding to 12 hours of observation. Data collection on basic behavioral patterns was based on sampling of instantaneous scanning or scanning (Altmann, 1974). The ingestive behavior was recorded every 10 minutes, observing the activity performed as grazing time, rumination, access to the creep-fed (only in the creep feeding treatment), time of consumption of mineral salt and lactation. The time spent with each activity was evaluated throughout the experimental period.

\subsection{Management of Pastures}

\subsubsection{Forage Mass}

The collection for evaluating the dry matter forage mass (Table 2) of the pasture was performed every 28 days, and 10 samples were collected per picket, using a metallic square of $0.25 \mathrm{~m}^{2}$ of area $(0.5 \mathrm{~m} \times 0.5 \mathrm{~m})$, in random points, representative of each picket. Areas close to the road were avoided. 


\subsubsection{Grass Height}

In the estimation of grass height (Table 3), the end was considered where the graduated ruler touched the highest leaf blade from the ground level. 30 samples were taken at each picket at 15-day intervals and then the mean height at each picket and per treatment was calculated.

\subsection{Bromatological Evaluation}

Supplement (offered and leftover) and pasture samples were oven dried at $55^{\circ} \mathrm{C}$ for 72 hours, and ground in a Willey mill equipped with a $1 \mathrm{~mm}$ sieve. The determination of dry matter $(\mathrm{DM})$, organic matter $(\mathrm{OM})$, crude protein $(\mathrm{CP})$ and ethereal extract $(\mathrm{EE})$ were performed according to AOAC (2000) using methods 930.15, 932.05, 976.05 and 920.39, respectively. The content of neutral detergent fiber (NDF) and acid detergent fiber (ADF) were determined according to Mertens (2002) (Table 3).

\subsection{Health Management}

At the time of delivery, all matrices received $1 \mathrm{ml}$ of an active principle based on avermectin subcutaneously to avoid infestation by myiasis. The lambs were weighed at birth and every seven days until weaning. All the sanitary management measures such as cutting and disinfecting the navel with iodine-based dyeing recommended for newborn lambs were adopted.

\subsection{Criteria for Weaning, Determination of Average Daily Gain (ADG) and Evaluation of Matrices}

The final weight of $20 \mathrm{~kg}$ was the criterion for weaning. For the determination of animal performance, average daily gain (ADG) in grams was calculated by the difference between weaning weight (WW) and birth weight (BW) divided by age (days) of the animals. The matrices were weighed every 14 days. Body condition score (BCS) assessments were performed through palpation and evaluation of the amount of muscle and fat of the transverse and dorsal processes of the lumbar vertebrae, giving scores of 1 to 5 (Russel et al. 1969).

\subsection{Parasitological Evaluation}

\subsubsection{Quantification of Larvae on Grass}

In order to quantify the infective larvae per kilogram of dry matter (L3/kg/DM) of the pasture, the forage was collected every 28 days by the method previously described. The samples were weighed and divided into two aliquots: one for determination of the dry matter and another was immersed in a bucket containing water and neutral detergent. The plant material was discarded from the bucket after decantation for 24 hours and the supernatant was removed. This material was transferred to funnels and refrigerated for six hours. The supernatants were removed and the infective larvae of the sedimented material were counted (Melo et al., 2017).

\subsubsection{Eggs Per Gram of Faeces - Treatment Criteria}

Lambs and matings were monitored parasitologically every 14 days and through analyzes of 
eggs per gram of feces (epg) (Gordon \& Whitlock, 1939) performed at the Laboratory of Parasitic Diseases of FAMEZ. For the identification of the nematode genus, coproculture was performed (Roberts \& O'Sullivan, 1950). Fecal samples were collected directly from the lamb's rectal ampulla to quantify the eggs per gram of faeces (epg). During the course of seven days a new collection of epg. was performed to identify the drop in egg numbers. After complete clinical recovery, the lambs and their mothers were reintroduced into the herd in their respective treatments.

\subsection{Hepatogenic Intoxication and Parasitological Infection - Criteria for Hospitalization}

On observing signs compatible with Brachiaria spp. or with gastrointestinal parasitology the lambs and their mothers were separated from the herd, taken to a shelter sheltered from the sun and fed alfalfa hay (Medicago sativa) as volumous, with access to water and mineral supplement at will.

\subsection{Experimental Design}

The experimental design was randomized blocks, according to the order of delivery, type of delivery and sex of the lambs in two treatments (Control or creep feeding) and 3 replicates (pickets) and analyzed according to the statistical model: $\mathrm{Yij}=\mathrm{m}+\mathrm{Ai}+\mathrm{Bj}+\mathrm{ABij}+\mathrm{eij}$, where: Yijk is the observed value for the variable (age at weaning, birth weight, weaning weight and average daily gain); $\mathrm{m}$ is the general constant; $\mathrm{Ai}$ is the treatment effect (control or creep feeding); $B j$ is the effect of $\operatorname{sex}(j=1,2)$; $A B i j$ is the effect of treatment $x$ sex interaction; eij is the random error associated with each observation.

\subsection{Statistical Analysis}

The performance data were evaluated through analysis of variance and the means were compared using the Tukey test at the 0.05 level of significance. Data on productive performance of the matrices at the time of delivery were evaluated by means of analysis of variance and the means compared by means of the Wilcoxon test at 0.05 level of significance. The results of e.p.g. and the number of anthelmintic treatments required for each animal were grouped into three distinct age groups: 31 to 452 days, 46 to 60 days and over 60 days, for the creep feeding and control treatments. The average number of $\mathrm{L} 3 / \mathrm{m}^{2}$ in the areas where the animals were kept supplemented or not compared according to these categories, but according to the months of the year. ANOVA was performed (treatment and age group), followed by the Bonferroni test to verify differences between groups at the $95 \%$ level of significance.

\section{Results}

\subsection{Productive Performance}

The lambs of the creep feeding treatment presented superior productive performance to the lambs of the control treatment. There was no change in mean birth weight $(\mathrm{kg})$ between treatments, conferring homogeneity of the lots. Lambs from control treatment and creep feeding treatment were born on average with 4.13 and $4.39 \mathrm{~kg}$, respectively. Likewise, it was observed that there was no difference between males and females, that is, both presented 
similar productive performance (Table 4).

The mean weight at weaning of $20 \mathrm{~kg}$ was the criterion used to determine the end of the experimental period. To achieve mean weight at weaning of $19.70 \mathrm{~kg}$, control lambs were weaned on average at 81 days of age. In the creep feeding treatment the lambs were weaned on average at $19.90 \mathrm{~kg}$, when they were on average at 58 days of age. There was a significant difference in GMD ( $\mathrm{g} /$ day) between treatments. Lambs from the control treatment had GMD of $194 \mathrm{~g} /$ day, while lambs from the creep feeding treatment had GMD of $268 \mathrm{~g} /$ day (Table 4).

Regardless of nutritional treatment, all matings received $350 \mathrm{~g} / \mathrm{day}$ of concentrated supplementation to meet maintenance and lactation requirements. The calving weight $(\mathrm{kg})$ of the matrices did not differ significantly between the nutritional treatments of lambs. Likewise, the nutritional treatment of the lambs did not influence the weaning weight $(\mathrm{kg})$ of the matrices. There was variation in body weight (BW) of the maturity matrices at weaning in both treatments (Table 5).

\subsection{Ingestive Behavior}

The time spent by lambs for feed intake was similar between treatments. In the control treatment the time of ingestion of the forage was higher after the 31 days of age, and remained similar until the lambs reached more than 60 days of age. In the treatment of creep feeding there was no difference in forage intake time at the different ages evaluated (Table 6).

The time for rumination did not differ between treatments. In the control treatment there was no difference in the time spent for rumination between the age groups. In the treatment creep feeding lambs in the age range of 0 to 30 days spent less time chewing than lambs over 31 days of age (Table 6).

The time of milk intake, drinking water, mineral supplementation and leisure time did not differ between treatments and nor between the age groups observed (Table 6).

The mean dry matter (DM) intake of the protein-energy supplement of lambs from the creep feeding treatment was $20.84 \mathrm{~g} / \mathrm{kg}$ body weight (BW).

\subsection{Parasitological Evaluation}

The amount of infective larvae recovered on a dry matter $(\mathrm{L} 3 / \mathrm{kg} / \mathrm{DM})$ in pastures was similar between treatments. The mean values were 6.62 and $6.12(\mathrm{~L} 3 / \mathrm{kg} / \mathrm{DM})$ in the control and creep feeding treatments, respectively.

Lambs from both treatments presented high egg counts per gram of faeces (epg). From the 46 days of age, control lambs presented higher epg than creep feeding lambs. Lambs from the control treatment presented increased epg. counts as the age progressed. In the creep feeding treatment, the lambs presented increased epg count in the age group of 46 to 60 days of age. From 60 days the epg. count decreased in this treatment (Table 7).

The epg of the matrices was similar between treatments and remained constant throughout the experimental period. The epg. count of the matrices in the control treatment ranged from 
554 to 769 and in the creep feeding treatment that variation was from 218 to 575 .

Monthly results of coproculture of the samples of all lambs indicated the predominance of the genus Haemonchus, with minority participation of Trichostrongylus and Oesophagostomum. Cooperia spp. was found to be only $0.1 \%$ in the groups. The frequencies of the nematode genera of the two groups were similar.

In all experimental period, 27 anti-helminthic administrations were performed in the lambs of the control treatment and 10 in the lambs of the creep feeding treatment. There was a significant effect in the age group above 60 days, when 15 administrations were performed in the lambs of the control treatment and three in the lambs of the creep feeding treatment.

There was no difference between the number of vigorous larvae recovered in the experimental pike during the study months, demonstrating a similar challenge by parasites in both groups.

\subsection{Morbidity Rate and Clinical Signs}

The morbidity rate of lambs from the control treatment was higher than that of the lambs from the creep feeding treatment. In the control treatment, a lamb was hospitalized with clinical signs corresponding to gastrointestinal verminosis. No lambs with clinical signs of gastrointestinal were observed in the creep feeding treatment. Of the 15 lambs of the control treatment seven presented clinical signs of intoxication by Brachiaria spp. In the treatment of 16 lambs, two were hospitalized with clinical signs of intoxication by Brachiaria spp. (Table 8).

The clinical signs corresponding to the gastrointestinal verminosis were apathy, submandibular edema and anemia of the ocular mucosa. Clinical signs of Brachiaria spp. Intoxication were hepatogenic photosensitization with restricted lesions on depigmented parts of the body or face. These lesions were characterized by alopecia, erythema, formation of crusts that were detached, leaving exposed areas of alopecia. In addition to anorexia, apathy, jaundice and weight loss.

\section{Discussion}

\subsection{Productive Performance}

The performance of lambs that received protein-energy supplementation in the creep feeding system was superior to lambs performance of the control treatment. There was a low variation in mean birth weight between treatments and lambs had a mean birth weight of 4.3 $\mathrm{kg}$, which made homogeneity in both groups. The mean lamb birth weight can be classified as adequate to sheep breeding patterns and is related to the good nutritional conditions of the matrices and to the reproductive genetics (Santos et al. 2017).

The observed pasture variables (DM yield, leaf ratio, stem ratio, dead matter ratio, leaf - stem height and height ratio) showed that the forage canopy of control and creep feeding treatments had similar grazing conditions for lambs. In both nutritional treatments, the lambs were available forage and milk intake at will. However, only milk and pasture intake do not meet the nutritional requirements of suckling lambs, especially if they are meat-producing 
animals and pasture is of poor quality. According to NRC (2007), a lamb of $20 \mathrm{~kg} \mathrm{BW}$, with an average gain of $200 \mathrm{~g} / \mathrm{day}$, presents as nutritional requirements: dry matter intake (DMI) of $0.594 \mathrm{~kg} /$ day, TDN of $0.39 \mathrm{~kg} /$ day and $111 \mathrm{~g} /$ day CP.

In order to study the chemical composition of the forage used, the foliar leaf, it is understood that the diet offered to the lambs of the control treatment, exclusively pasture and milk ingestion, was not effective to accelerate the weight gain of these animals. In this case, protein-energy supplementation emerged as an alternative to meet the maintenance and gain requirements of suckling lambs and to enhance the available fodder resources. The effects observed were determined by the quality of the forage and the nutritional requirement of the lambs.

\subsection{Ingestive Behavior}

The best performance observed in the creep feeding lambs can be explained by the associative effect of the supplement on forage intake and dietary digestible energy (Moore et al. 1999). The inclusion of the supplement could reduce the consumption of the forage, characterizing the substitutive effect. However, it was observed through the ingestive behavior that the time used for the consumption of the forage (hours) by the lambs did not differ between the treatments. Thus, it was observed that the additive effect occurred, with the total dry matter intake (pasture + supplement) and increase of the weight gain of the lambs. This fact is explained by the low nutritional value of Brachiaria spp. associated to the reduced $\mathrm{CP}$ and TDN contents and to the high fiber content (NDF), characteristics closely related to DMI (Silva et al. 2009), because they present slow rate of passage through the gastrointestinal tract and low degradation of the fiber. In this case, the consumption was not significantly reduced when the supplement was supplied, since under these conditions, the voluntary consumption of the forage is already low.

The rumination time (hours) did not differ between the treatments, confirming that the quality of the forage ingested by the lambs in the different nutritional treatments was similar. The time for rumination is related to the nature of the diet, being proportional to the cell wall content of the bulky ones. Thus, the higher the fiber content in the diet, the longer the time spent in rumination (Van Soest, 1994, Poli et al. 2009).

The time for milk intake (hours) did not differ, demonstrating that during the experimental period milk production was similar among the nutritional treatments of lambs. This was explained by the supplementation of $350 \mathrm{~g}$ per animal/day that all matings received during the experimental period, independently of the nutritional treatment of lambs. Although there was no significant difference between the treatments and in the different age ranges, it was observed that the lambs spent more time on breastfeeding until the 30 days of age. The milk lactation curve shows higher milk production in the first four weeks and a decrease from the 8th week, which may lead lambs to perform poorly due to the low supply of nutrients to support the high capacity of weight gain of this category (Mckusick et al. 2001). These results demonstrate that the addition of the protein-energetic supplement in the creep feeding system was fundamental for the better performance presented by the lambs of this treatment.

It was observed that the productive performance of the lambs was not influenced by the 
nutritional treatments of the lambs, since the birth weight $(\mathrm{kg})$, the weaning weight $(\mathrm{kg})$ and the BSC variation did not have significant differences among the matrices. This fact can be confirmed by breastfeeding (hours) and lambs' birth weight, similar between treatments. On the other hand, the control and creep feeding ewes showed a significant difference in body weight variation (difference between birth weight and weaning weight). This variation can be explained by the physiological and metabolic changes that occur in the sheep in the lactation phase, especially in the first weeks. At this stage, the energy balance is negative and the sheep have to meet their maintenance and milk production requirements. As a result, at the same time as food intake and nutrients are being absorbed from the gastrointestinal tract, there is also mobilization of fat and protein from the adipose and muscular tissues (Santos et al. 2017). Therefore supplementation $(\mathrm{CP}=163.9$ and $\mathrm{TDN}=812.8 \mathrm{~g} / \mathrm{kg} \mathrm{BW})$ offered during lactation was essential to meet the nutritional requirements of the matrices, independently of the supplementation received by lambs.

\subsection{Physiological Factors}

Concurrently with the previously described factors, the best performance of lambs from the creep feeding treatment, when compared to control lambs is related to biochemical and physiological factors. The most important physiological factor determining the best performance is the ability to use solid foods to accelerate the development of the rumen, still in the lactation phase. In order to achieve satisfactory growth and stimulate ruminal development, lambs should receive a promptly fermentable diet that does not lead to an accumulation of hard-to-digest fibrous material within the rumen. In the case of creep feeding lambs, the diet provided better ruminal epithelial conditions by increasing the number and size of the papillae. The formation of the papillae is of extreme nutritional importance, as it increases the absorptive surface of the rumen (Bittar et al. 2009, NRC, 1985, Van Soest, 1994). These changes are caused by the higher propionate:acetate proportion produced from the intake of the protein supplement. The propionate absorbed by the ruminal wall is the main glycogenic substrate for the ruminant. Gluconeogenesis is of fundamental importance for the maintenance of plasma glucose levels in the ruminant, since the net absorption of glucose by the gastrointestinal tract is low. Thus, glucose anabolism becomes more efficient and allows more deposition of tissue, especially muscle tissue, with consequent weight gain of lambs supplemented (Baldwin et al. 2004). In the case of lambs fed only pasture and milk, they were probably unable to develop the rumen efficiently due to the lower production of propionate produced by the diet, and thus presented lower productive performance than the creep feeding lambs.

\subsection{Parasitological Evaluation}

The number of infective larvae was recovered on a dry matter basis (L3/ha/DM) showed no significant difference between treatments, demonstrating that lambs had similar parasitic challenge in both nutritional groups.

In both treatments the lambs presented high parasitic load. This fact is explained by the fact that suckling lambs born and kept in pasture are exposed to infection by infective larvae (L3) hatched from nematode eggs from the feces of the matrices themselves. At the same time, 
lambs do not yet have the developed immune system, making them one of the categories most susceptible to parasitic infection (Melo et al. 2017).

In addition to the positive effect of supplementation on productive performance of creep feeding lambs, better responses to parasitism can be observed. From the 46 days of age the epg of the lambs of the control treatment was superior to the epg of the lambs creep feeding. The total epg average was 4553 and 763 for the control and creep feeding treatments, respectively.

This higher count in control lambs occurred because parasitism had more severe effects on lambs with low protein intake. These changes are caused by the increased requirement because of the loss of endogenous nitrogen within the gut and the lesser degree of protein synthesis in the muscle in order to establish the losses occurring in the tissue. In addition to the diversion of nutrients, which would be used for weight gain, they are used to repair tissue damage caused by parasitism (Coop \& Kyriazakis, 1999).

In the case of lambs from the creep feeding treatment, protein-energy supplementation was able to increase tolerance and resistance of the host to parasitism. This was because the protein increment is associated with reduced epg and increased immunity, with higher antibody production coupled with reduced survival or fecundity of gastrointestinal nematodes (Torre-Acosta et al. 2012).

It was observed that in lambs from the creep feeding treatment fewer anthelmintic administrations were performed than in lambs from the control treatment. The reduction was significant in the age group over 60 days, with 15 administrations in the control treatment and three in the creep feeding treatment. In this case, it is evident that the protein-energy supplementation used for suckling lambs is a sustainable alternative to control parasitic infections and to make less use of anthelmintics (Melo et al. 2017).

Although there was no significant difference between the treatments, there was a progressive increase in the epg count of the matrices from the beginning to the end of the experimental period. This fact is related to grazing, because even with a variable stocking rate, the matrices remained in continuous grazing for a prolonged period, which certainly favored the continuous infestation of larvae (L3), through the elimination of the eggs of the sheep themselves (Basseto et al. 2009).

Haemonchus contortus was the genus with the highest prevalence in lambs, independently of the treatment, confirming that this species is among the most prevalent nematodes in Brazil (Amarante et al. 2004; Melo et al. 2017).

\subsection{Morbidity Rate and Clinical Signs}

The protein-energy supplementation offered to lambs from the creep feeding treatment affected the morbidity rates of lambs. Despite the high epg counts observed in both treatments, only one death was caused by gastrointestinal parasitism in the control treatment. In the treatment of creep feeding, no deaths caused by this disease were observed. Therefore, it is evident that the protocol adopted for feeding was efficient for both treatments. The 
clinical signs of the hospitalized lamb were apathy, submandibular edema and ocular mucosa anemia (Melo et al. 2017), characteristic of gastrointestinal parasitosis.

Clinical signs of Brachiaria spp. Intoxication were observed. in the lambs of both treatments. However, the morbidity rate of this disease was $46.7 \%$ and $12.5 \%$ for control and creep feeding treatments, respectively. In this case, it is evident that protein-energy supplementation reduced the effects of intoxication. This result is related to the physiological and biochemical changes of the rumen and, consequently, to changes in ruminal $\mathrm{pH}$ and microbiota. All these modifications influence hepatic lesions, since they are due to the chemical transformations of the saponins that occur in the rumen (Milles et al. 1991). Despite the vast literature on Brachiaria spp. Intoxication, studies on alternatives to control or minimize losses from this disease are still scarce. Work on genetic resistance to the disease and ways of adapting to the consumption of Brachiaria spp. without causing productive losses to lambs (Faccin et al. 2014; Pupin et al. 2016; Castro et al. 2018). However, in these studies, the measures adopted refer to experimental flocks and are difficult to control and perform in commercial herds. It was verified with the present work that the protein-energetic supplementation in addition to decreasing the morbidity rate in relation to the intoxications by Brachiaria spp. can be a viable alternative from a productive point of view. The clinical signs observed are related to Brachiaria spp. Intoxication. and the depigmented parts of the body or face were characterized by hepatogenic photosensitization with restricted lesions. These lesions were characterized by alopecia, erythema, and the formation of crusts, leaving exposed areas of alopecia and anorexia, apathy, jaundice and weight loss (Faccin et al. 2014; Pupin et al. 2016).

\section{Conclusion}

We conclude that the consumption of protein-energetic supplement $(20.84 \mathrm{~g} / \mathrm{kg} \mathrm{BW})$ in creep feeding for lambs fed with Brachiaria spp. provides higher daily gain and lower weaning age.. Protein-enriched supplementation increase resistance and tolerance to gastrointestinal infections, significantly reduce the use of anthelmintics, and reduce the morbidity rate related to Brachiaria spp intoxication of lambs on suckling. 
Table 1. Dry matter (DM) contents in $\mathrm{g} / \mathrm{kg}$, organic matter $(\mathrm{OM})$, mineral matter (MM), crude protein $(\mathrm{CP})$, ethereal extract (EE), neutral detergent fiber (NDF), total digestible nutrients , non-fibrous carbohydrates (NFC) of the concentrate $(\mathrm{g} / \mathrm{kg} \mathrm{DM})$ offered in the treatment of creep feeding and the concentrate in $(\mathrm{g} / \mathrm{kg} \mathrm{DM})$ offered the ewes

\begin{tabular}{lcc}
\hline & Concentrate Creep Feeding* & Concentrate Matrices $^{*}$ \\
\hline $\mathrm{DM}(\mathrm{g} / \mathrm{kg})$ & 897.9 & 900.1 \\
$\mathrm{OM}(\mathrm{g} / \mathrm{kg} \mathrm{DM})$ & 932.0 & 904.0 \\
$\mathrm{CP}(\mathrm{g} / \mathrm{kg} \mathrm{DM})$ & 230.3 & 163.9 \\
$\mathrm{EE}(\mathrm{g} / \mathrm{kg} \mathrm{DM})$ & 26.4 & 27.7 \\
$\mathrm{NDF}(\mathrm{g} / \mathrm{kg} \mathrm{DM}))$ & 143.2 & 170.5 \\
$\mathrm{TDN}(\mathrm{g} / \mathrm{kg} \mathrm{DM})^{\S}$ & 828.4 & 812.8 \\
$\mathrm{NFC}(\mathrm{g} / \mathrm{kg} \mathrm{DM})$ & 532.1 & 541.9 \\
\hline
\end{tabular}

*Ingredients (g/kg): 517.0 corn; 472.0 soybean meal; 10 of premix mineral;

\#Ingredients (g/kg): 761.1 corn; 198.9 soybean meal; 40 of calcium carbonate;

${ }^{\S}$ Estimated value by the equation of Cappelle et al (2001): TDN $=91.0246-0.571588 *$ NDF.

Table 2. Production of dry matter (DM) of forage, proportion of leaves, stem and dead material, leaf: stem ratio and height of Brachiaria spp. depending on the treatments

Treatments

\begin{tabular}{lcc}
\hline & Control & Creep Feeding \\
\hline Production of DM (kg/ha) & 5014.3 & 7837.5 \\
Proportion of leaves (\%) & 10.3 & 11.6 \\
Proportion of stem (\%) & 18.4 & 18.4 \\
Proportion of dead material leaf $(\%)$ & 71.4 & 70.9 \\
Leaf ratio: high & 0.5 & 0.6 \\
Height $(\mathrm{cm})$ & 33.0 & 34.1 \\
\hline
\end{tabular}


Table 3. Dry matter (DM) contents in $\mathrm{g} / \mathrm{kg}$, organic matter $(\mathrm{OM})$, crude protein $(\mathrm{CP})$, neutral detergent fiber (NDF), acid detergent fiber (ADF) and total digestible nutrients (TDN) of forage leaflets composed of Brachiaria spp. depending on the treatments

\begin{tabular}{lcc}
\hline & \multicolumn{2}{c}{ Treatments } \\
\cline { 2 - 3 } & Control & Creep Feeding \\
\hline $\mathrm{DM}(\mathrm{g} / \mathrm{kg})$ & 498.2 & 535.1 \\
$\mathrm{OM}(\mathrm{g} / \mathrm{kg}$ de $\mathrm{DM})$ & 922.1 & 907.0 \\
$\mathrm{CP}(\mathrm{g} / \mathrm{kg}$ de $\mathrm{DM})$ & 76.2 & 71.3 \\
$\mathrm{FDN}(\mathrm{g} / \mathrm{kg}$ de DM$)$ & 713.7 & 716.4 \\
$\mathrm{ADF}(\mathrm{g} / \mathrm{kg}$ de DM$)$ & 367.9 & 394.3 \\
$\mathrm{TDN}(\mathrm{g} / \mathrm{kg}$ de $\mathrm{DM})$ & 544.1 & 542.9 \\
\hline
\end{tabular}

*Values estimated by the equation of Cappelle et al (2001): TDN $=83.79-0.4117 *$

NDF. 
Table 4. Weight at birth (WB), weaning weight (WW), weaning age (WA), mean daily gain (ADG) of suckling lambs supplemented in creep feeding during the experimental period

\begin{tabular}{|c|c|c|c|c|c|c|c|c|}
\hline \multirow[b]{2}{*}{ Variable } & \multirow[b]{2}{*}{ Gender } & \multicolumn{3}{|c|}{ Treatments } & \multirow[b]{2}{*}{$\mathrm{SEM}^{*}$} & \multicolumn{3}{|c|}{ Value-P- } \\
\hline & & Control & Creep & Mean & & Gender & Treatment & $\mathrm{G}^{*} \mathrm{~T}^{\#}$ \\
\hline WB & Male & 4.1 & 4.4 & 4.3 & & & & \\
\hline \multirow[t]{2}{*}{$(\mathrm{kg})$} & Female & 4.1 & 4.3 & 4.2 & 0.33 & 0.801 & 0.593 & 0.856 \\
\hline & Mean & 4.1 & 4.4 & 4.3 & & & & \\
\hline WW & Male & 20.8 & 20.7 & 20.7 & & & & \\
\hline \multirow[t]{2}{*}{$(\mathrm{kg})$} & Female & 18.6 & 19.2 & 18.9 & 0.71 & 0.104 & 0.838 & 0.739 \\
\hline & Mean & 19.7 & 19.9 & 19.8 & & & & \\
\hline WA & Male & 82 & 59 & 69 & & & & \\
\hline \multirow[t]{2}{*}{ (days) } & Female & 80 & 57 & 70 & 6.00 & 0.830 & 0.005 & 1.000 \\
\hline & Mean & $81 \mathrm{a}$ & $58 b$ & 70 & & & & \\
\hline $\mathrm{ADG}$ & Male & 206 & 278 & 242 & & & & \\
\hline \multirow[t]{2}{*}{ (g/day) } & Female & 181 & 259 & 220 & 0.02 & 0.257 & 0.003 & 0.880 \\
\hline & Mean & $194 b$ & $268 \mathrm{a}$ & 231 & & & & \\
\hline
\end{tabular}

Different lowercase letters on the same line indicate significant difference by the Tukey test

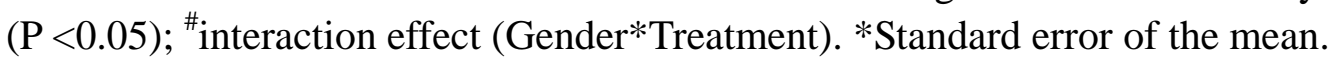


Table 5. Body weight $(\mathrm{kg})$, body condition score (BCS) and weight variation $(\mathrm{kg})$ and body condition (BCS) score of ewes at calving and weaning in creep feeding and control treatments

\begin{tabular}{|c|c|c|c|c|}
\hline & \multicolumn{2}{|c|}{ Treatment* } & \multirow{2}{*}{$\mathrm{SEM}^{\S}$} & \multirow{2}{*}{$\mathrm{P}$} \\
\hline & Control & Creep feeding & & \\
\hline Weight at birth (kg) & $51.3 \mathrm{a}$ & $48.2 \mathrm{a}$ & 0.33 & 0.344 \\
\hline Weight at weaning $(\mathrm{kg})$ & $47.9 \mathrm{~b}$ & $46.6 b$ & 0.30 & 0.634 \\
\hline $\mathrm{BW}$ variation (kg) & -3.4 & -1.6 & 0.12 & 0.145 \\
\hline $\mathrm{BCS}^{\#}$ at birth & 2.6 & 2.2 & 0.03 & 0.196 \\
\hline $\mathrm{BCS}^{\#}$ at Weaning & 2.0 & 1.7 & 0.79 & 0.345 \\
\hline $\mathrm{BCS}$ variation & -0.6 & -0.5 & 0.03 & 0.698 \\
\hline
\end{tabular}

* Means followed by lower-case distinct letters in the column, differ by Wilcoxon test ( $\mathrm{P}$ $<0.05$ ), for body weight and BCS variables; ${ }^{\#} \mathrm{BCS}=$ Body condition score, rated on a scale of 1 to 5 (Russel et al.,1969); ${ }^{\S}$ Standard error of the mean. 
Table 6. Ingestive behavior of lambs of control and creep-feeding treatments

\begin{tabular}{|c|c|c|c|c|}
\hline \multirow[t]{2}{*}{ Age (days) } & \multicolumn{2}{|c|}{ Activity } & \multirow{2}{*}{$\mathrm{SEM}^{\S}$} & \multirow{2}{*}{$P$} \\
\hline & Control & Creep feeding & & \\
\hline & \multicolumn{2}{|c|}{ Grazing $(\mathrm{h})^{\#}$} & & \\
\hline $0-30$ & $2.81 \mathrm{~b}$ & 3.13 & 0.56 & 0.680 \\
\hline $31-45$ & $4.68 \mathrm{a}$ & 4.45 & 0.27 & 0.538 \\
\hline $46-60$ & $5.96 \mathrm{a}$ & 4.44 & 0.57 & 0.062 \\
\hline$>60$ & $6.22 \mathrm{a}$ & 4.94 & 0.84 & 0.242 \\
\hline Mean & 4.75 & 4.08 & 0.30 & 0.227 \\
\hline SEM & 0.51 & 0.71 & & \\
\hline \multirow[t]{2}{*}{$P$} & $<0.001$ & 0.075 & & \\
\hline & \multicolumn{2}{|c|}{ Ruminating $(\mathrm{h})^{\#}$} & & \\
\hline $0-30$ & 0.71 & $0.32 b$ & 0.20 & 0.189 \\
\hline $31-45$ & 0.97 & $1.12 \mathrm{a}$ & 0.16 & 0.477 \\
\hline $46-60$ & 1.47 & $0.93 \mathrm{ab}$ & 0.22 & 0.084 \\
\hline$>60$ & 0.97 & $1.14 \mathrm{a}$ & 0.30 & 0.654 \\
\hline Mean & 1.00 & 0.84 & 0.11 & 0.405 \\
\hline SEM & 0.26 & 0.22 & & \\
\hline \multirow[t]{2}{*}{$P$} & 0.175 & $<0.001$ & & \\
\hline & \multicolumn{2}{|c|}{ Suckling $(\mathrm{h})$} & & \\
\hline $0-30$ & 0.49 & 0.38 & 0.15 & 0.614 \\
\hline $31-45$ & 0.29 & 0.22 & 0.06 & 0.439 \\
\hline $46-60$ & 0.12 & 0.08 & 0.06 & 0.646 \\
\hline$>60$ & 0.08 & 0.21 & 0.09 & 0.300 \\
\hline \multirow[t]{2}{*}{ Mean } & 0.27 & 0.26 & 0.06 & 0.560 \\
\hline & 0.11 & 0.14 & & \\
\hline \multicolumn{5}{|l|}{ SEM } \\
\hline$P$ & 0.057 & 0.272 & & \\
\hline \multicolumn{5}{|c|}{ Feeding, supplement (h) } \\
\hline $0-30$ & 0.00 & 0.46 & 0.05 & $<0.001$ \\
\hline $31-45$ & 0.00 & 0.71 & 0.09 & $<0.001$ \\
\hline $46-60$ & 0.00 & 0.63 & 0.11 & 0.001 \\
\hline$>60$ & 0.00 & 0.89 & 0.19 & 0.003 \\
\hline Mean & 0.00 & 0.64 & 0.05 & $<0.001$ \\
\hline SEM & 0.00 & 0.19 & & \\
\hline$P$ & & 0.231 & & \\
\hline
\end{tabular}

* Other activities (drinking water intake, mineral and leisure) responded for 12 hours of

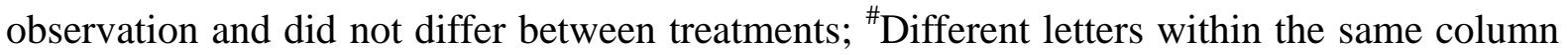
and category indicate significant difference $(\mathrm{P}<0.05)$; ${ }^{\S}$ Standard error of the mean. Data adapted from Melo et al. (2017). 
Table 7. Egg count per gram of faeces (EPG) in lambs submitted to creep feeding and control treatments according to age

\begin{tabular}{|c|c|c|c|c|c|c|}
\hline \multirow{2}{*}{ Age (days) } & \multicolumn{3}{|c|}{ Control } & \multicolumn{3}{|c|}{ Creep feeding } \\
\hline & $\begin{array}{c}\text { Mean } \\
\text { EPG }\end{array}$ & SEM $^{\#}$ & $\begin{array}{l}\text { Range of } \\
\text { variation }\end{array}$ & $\begin{array}{l}\text { Mean } \\
\text { EPG }\end{array}$ & SEM $^{\#}$ & $\begin{array}{l}\text { Range of } \\
\text { variation }\end{array}$ \\
\hline $31-45^{*}$ & $1088 \mathrm{a}$ & 1253 & $0-2650$ & $170 \mathrm{a}$ & 260 & $0-750$ \\
\hline $46-60 *$ & $4108 \mathrm{a}$ & 3798 & $0-11050$ & $1719 b$ & 1864 & $0-5200$ \\
\hline$>60 *$ & $8462 a$ & 3798 & $0-44150$ & $400 \mathrm{~b}$ & 404 & $100-1250$ \\
\hline Mean & 4553 & 3707 & & 763 & 836 & \\
\hline
\end{tabular}

*Different letters on the same line indicate a significant difference $(\mathrm{P}<0.05)$ by the Bonferroni test; ${ }^{\#}$ Standard error of the mean.

Table 8. Morbidity rate for gastrointestinal parasitosis and Brachiaria intoxication, for control and creep feeding treatments

Treatment

Productive Indices

Control Creep feeding

Morbity $^{\#}-$ parasitosis $(\%)$

$6.67(1 / 15)$

Morbity ${ }^{\#-B r a c h i a r i a}$ intoxication $(\%)$

$46.67(7 / 15)$

$12.50(2 / 16)$

*Control Treatment = 15 lambs; Treatment Creep Feeding = 16 lambs;

\#Morbidity rate (number of sick animals from birth to weaning/number of category animals) 


\section{References}

Altmann, J. (1974). Observational study of behavior sampling methods. Behaviour, 49, 227-267. https://doi.org/10.1163/156853974X00534

Amarante, A. F. T., Bricarello, P. A., Rocha, R. A., \& Gennari, S. M. (2004). Resistance of Santa Inês, Suffolk and Ile de France sheep to naturally acquired gastrointestinal. Veterinary Parasitology, 120, 91-106. https://doi.org/10.1016/j.vetpar.2003.12.004.

Association of Official Analytical Chemists (2000). Official Methods of Analysis of AOAC International. 17 th ed., Gaithersburg, MD, USA.

Baldwin, R. L., Mcleod, K. R., Klotz, J. L., \& Heitmann, R. N. (2004). Rumen development, intestinal growth and hepatic metabolism in the pre- and postweaning ruminant. Journal of Dairy Science, 87, 55-65. https://doi.org/10.3168/jds.S0022-0302(04)70061-2.

Basseto, C. C., Silva, B. F., Fernandes, S., \& Amarante, A. F. T. (2009). Pasture contamination with infective larvae of gastrointestinal nematodes after grazing by sheep resistant or susceptible to parasitic infection. Revista Brasileira de Parasitologia Veterinária, 18, 63-68. https://doi.org/10.4322/rbpv.01804012

Bittar, C. M. M., Ferreira, L. S., Santos, F. A. P., \& Zopollatto, M. (2009). Performance and ruminal development of dairy calves fed starter concentrate with different physical forms. Revista Brasileira de Zootecnia, 38, 1561-1567.

https://doi.org/10.1590/S1516-35982009000800021

Cappelle, E. R., Valadares Filho, S. C., Silva, J. F. C., \& Cecon, P. R. (2001). Estimates of the energy value from chemical characteristics of the feedstuffs. Revista Brasileira de Zootecnia, 30, 1837-1856. https://doi.org/10.1590/S1516-35982001000700022

Castro, M. B., Gracindo, C. V., Landi, M. F. A., Cabral Filho, S. L. S., Resende Filho, N. J., Lima, E. M. M., \& Riet-Correa, F. (2018). Sheep adaptation management, and investigation of inherited resistence to prevent Brachiaria spp. poisoning. Small Ruminant Research, 158, 42-47. https://doi.org/10.1016/j.smallrumres.2017.12.001

Coop, R. L., \& Kyriazakis, I. (1999). Nutrition-parasite interaction. Veterinary Parasitology, 84, 187-204. https://doi.org/10.1016/S0304-4017(99)00070-9

Emerenciano Neto, J. V., Difante, G. S., Lana, Â. M. Q., Medeiros, H. R., Aguiar, E. M., Montagner, D. B., \& Souza, J. S. (2019). Forage quality and performance of sheep in Massai grass pastures managed at pre-grazing canopy heights. South African Journal of Animal Science, 48, 1074-1081. https://doi.org/10.4314/sajas.v48i6.10

Euclides, V. P. B., Macedo, M. C. M., Valle, C. B., Difante, G. S., Barbosa, R. A., \& Cacere, E. R. (2009). Forage nutritive value and animal production in Brachiaria brizantha pastures. Pesquisa Agropecuária Brasileira. 44, 98-106.

https://doi.org/10.1590/S0100-204X2009000100014

Faccin, T. C., Riet-Corrêa, F., Rodrigues, F. S., Santos, A. C., Melo, G. K. A., Silva, J. A., ... 


\section{Mll Macrothink}

Journal of Agricultural Studies

ISSN 2166-0379

2019, Vol. 7, No. 4

Lemos R. A. A. (2014). Poisoning by Brachiaria brizantha in flocks of naïve and experienced sheep. Toxicon, 82, 1-8. https://doi.org/10.1016/j.toxicon.2014.02.008

Garcia, C. A., Costa, C., Monteiro, A.L. G., Neres, M. A., \& Rosa, G. J. M. (2003). Performance and carcass traits of lambs fed diets with different energy levels grown in creep feeding. Revista Brasileira de Zootecnia, 32, 1371-1379. https://doi.org/10.1590/S1516-35982003000600012

Gordon, H. M. C. L., \& Whitlock, H. V. (1939). A new technique for counting nematode eggs in sheep faeces. Journal of the Council for Scientific and Industrial Research, 12, 50-52.

Louvandini, H., Veloso, C. F. M., Paludo, G. R., Dell' Porto, A., Gennari, S. M., \& McManus, C. M. (2006). Influence of protein supplementation on the resistance and resilience on young hair sheep naturally infected with gastrointestinal nematodes during rainy and dry seasons. Veterinary Parasitology, 137, 103-111. https://doi.org/10.1016/j.vetpar.2006.01.004

Mckusick, B. C., Thomas, D. L., \& Berger, Y. M. (2001). Effect of system on commercial milk production and lamb growth of East Friesian dairy sheep. Journal of Dairy Science, 84, 1660-1668. https://doi.org/10.3168/jds.S0022-0302(01)74601-2

Melo, G. K. A., Ítavo, C. C. B. F., Monteiro, K. L. S., Silva, J. A., Silva, P. C. G., Ítavo, L. C. V., ... Borges, F. A. (2017). Effect of creep-fed supplement on the susceptibility of pasture-grazed suckling lambs to gastrointestinal helminthes. Veterinary Parasitology, 239, 26-30. https://doi.org/10.1016/j.vetpar.2017.04.017

Melo, G. K. A., Ítavo, C. C. B. F., Silva, J. A., Monteiro, K. L. S., Faccin, T. C., Pupinha, R. C., ... Lemos, R. A. A. (2018). Poisoning by Brachiaria spp. in suckling lambs supplemented and unsupplemented in a creep-feeding system. Small Ruminant Research, 158, 30-34. https://doi.org/10.1016/j.smallrumres.2017.11.014

Mertens, D. R. (2002). Gravimetric determination of amylase-treated neutral detergent fiber in feeds with refluxing in beaker or crucibles: collaborative study. Journal of AOAC International, 85, 1217-1240.

Milles, C. O., Munday, S. C., Holland, P. T., Smith, B. L., Embling, P. P., \& Wilkins, A. L. (1991). Identification of a sapogenin glucoronide in the bile of sheep affected by Panicum dichotomiflorum toxicosis. New Zealand Veterinary Journal, 39, 150-152. https://doi.org/10.1080/00480169.1991.35684

Moore, J. E., Brant, M. H., Kunkle, W. E., \& Hopkins, D. I. (1999). Effects of supplementation on voluntary forage, diet digestibility and animal performance. Journal of Animal Science. 77, 122-135. https://doi.org/10.2527/1999.77suppl_2122x

National Research Council - NRC. (2007). Nutrient requirements of small ruminants: sheep, goats, cervids and new world camelids. Washington: National Academy Press, 362p.

National Research Council, NRC. (1985). Nutrient Requirements of Small Ruminants. Washington: National Academy Press. 99p. 
Oliveira, J. S., Emerenciano Neto, J. V., Santos, R. S., Bonfim, B. R. S., Lista, F. N., Vieira, V. A., \& Difante, G. S. (2019). Structural and Productive Characteristics of Urochloa Cultivars Submitted to Different Defoliation Frequencies in Semiarid Region. Journal of Agricultural Studies, 7, 91-102. https://doi.org/10.5296/jas.v7i3.15177

Poli, C. H. E. C., Monteiro, A. L. A., Barros, C. S., Dittrich, J. R., Fernandes, S. R., \& Carvalho, P. C. F. (2009). Intake behavior of lambs in three production systems on Tifton 85 pasture. Acta Scientiarum. Animal Sciences, 31, 235-241.

https://doi.org/10.4025/actascianimsci.v31i3.6014

Pupin, R. C., Melo, G. K. A., Heckler, R. F., Faccin, T. C., Ítavo, C. C. B. F., Fernandes, C. E., ... Lemos, R. A. A. (2016). Identification of lamb flocks susceptible and resistant against Brachiaria poisoning. Pesquisa Veterinaria Brasileira. 36, 383-388. https://doi.org/10.1590/S0100-736X2016000500005

Roberts, F. H. C., \& O’Sullivan, J. P. (1950). Methods for egg counts and larval cultures for strongyles infesting the gastrointestinal tract of cattle. Australian Journal of Agricultural Research, 1, 99-102. https://doi.org/10.1071/AR9500099

Russel, A. J. F., Dooney, J. M., \& Gunn, R. G. (1969). Subjective assessment of body fat in live sheep. The Journal of Agricultural Science, 72, 451-454.

https://doi.org/10.1017/S0021859600024874

Santos, M. P., Godoy, M. M., Souza, C. L., Assis, R. M., \& Sena, C. V. B. (2017). Productive and reproductive performances of Santa Inês ewes fed diets supplemented with protected fat in the postpartum. Pesquisa Agropecuaria Brasileira, 52, 548-556.

https://doi.org/10.1590/s0100-204x2017000700009

Silva, F. F., Sá, J. F., Schio, A. R., Ítavo, L. C. V., Silva, R.R ., \& Mateus, R. G. (2009). Grazing supplementation: availability and quality x supplementation levels x performance. Revista Brasileira de Zootecnia, 39, 371-389.

https://doi.org/10.1590/S1516-35982009001300037

Torres-Acosta, J. F. J., Sandoval-Castro, C. A., \& Hoste, H. (2012). Nutritional manipulation of sheep and goats for the control of gastrointestinal nematodes under hot umid and subhumid tropical conditions. Small Ruminant Research, 103, 28-40.

https://doi.org/10.1016/j.smallrumres.2011.10.016

Van Soest, P. J. (1994). Nutritional ecology of the ruminant. 2th ed. Ithaca, Cornel University Press.

\section{Copyright Disclaimer}

Copyright for this article is retained by the author(s), with first publication rights granted to the journal.

This is an open-access article distributed under the terms and conditions of the Creative Commons Attribution license (http://creativecommons.org/licenses/by/4.0/). 